\title{
Characteristics and Microbial Succession in Co-Composting of Oil Palm Empty Fruit Bunch and Partially Treated Palm Oil Mill Effluent
}

\author{
Azhari Samsu Baharuddin ${ }^{1,2}$, Nakamura Kazunori ${ }^{4}$, Suraini Abd-Aziz*,3, Meisam Tabatabaei ${ }^{3}$, \\ Nor' Aini Abdul Rahman ${ }^{3}$, Mohd Ali Hassan ${ }^{3}$, Minato Wakisaka ${ }^{1}$, Kenji Sakai ${ }^{4}$ and \\ Yoshihito Shirai $^{1}$
}

\author{
${ }^{I}$ Department of Biological Functions and Engineering, Graduate School of Life Science and System Engineering, \\ Kyushu Institute of Technology, 2-4 Hibikino, Wakamatsu-ku, Kitakyushu, Fukuoka 808-0916, Japan \\ ${ }^{2}$ Department of Process and Food Engineering, Faculty of Engineering, Universiti Putra Malaysia, 43400 UPM \\ Serdang, Selangor, Malaysia \\ ${ }^{3}$ Department of Bioprocess Technology, Faculty of Biotechnology and Biomolecular Sciences, Universiti Putra \\ Malaysia, 43400 UPM Serdang, Selangor, Malaysia \\ ${ }^{4}$ Department of Plant Resources, Graduate School of Bioresources and Bioenvironmental Sciences, Kyushu University, \\ 6-10-1, Higashi-ku, Fukuoka, 812-8581, Japan
}

\begin{abstract}
Microbial communities and cellulolytic enzymes activities were analyzed during the co-composting of empty fruit bunch (EFB) and partially treated palm oil mill effluent (POME) in pilot scale. The physicochemical parameters were also measured during the composting. The diversity of the bacterial community was investigated using polymerase chain reaction-denaturing gradient gel electrophoresis (PCR-DGGE). The results indicated that the composting process of EFB with partially treated POME was dominated by uncultured bacteria species. The dominant bacterial group changed from the phylum proteobacteria in the thermophilic stage to the phylum chloroflexi in the maturing stage. Scanning electron microscope (SEM) analysis exhibited the significant degradation of EFB structure during the composting process. The maximum cellulase activity for carboxymethylcellulase (CMCase), filter paperase (FPase) and $\beta$-glucosidase were 13.6, 4.1 and $20.3 \mathrm{U} / \mathrm{g}$ of dry substrate, respectively at day 30 of composting. The results of this study significantly contributed to a better understanding of mechanisms involved in co-composting process in pilot scale.
\end{abstract}

Keywords: Composting, empty fruit bunch, partial treated palm oil mill effluent, cellulase, DGGE.

\section{INTRODUCTION}

Oil palm production is a major agricultural industry in Malaysia. The oil palm biomass (OPB) produces about 40 million tonnes per year. This OPB can be categorized as a form of empty fruit bunches (EFB), oil palm trunks (OPT) and oil palm fronds (OPF) and the rest are palm oil mill effluent (POME). Composting has been considered to be one of the most suitable ways of converting organic wastes into products that are beneficial for plant growth. Thus, the utilization of EFB and POME as substrate for the composting is crucial to convert into value added product and treat the biomass simultaneously.

In our previous work, it showed that co-composting of EFB and partially treated POME can be used as an alternative method for converting of these materials using a simple and traditional windrow composting piles in pilot scale [1]. Although considerable research on composting of various organic wastes has been conducted [2,3], little information on characteristics and microbial changes from EFB and

*Address correspondence to this author at the Department of Bioprocess Technology, Faculty of Biotechnology and Biomolecular Sciences, Universiti Putra Malaysia, 43400 Serdang, Selangor, Malaysia; Tel: +6-0389467479; Fax: +6-03-89467510; E-mail: suraini@biotech.upm.edu.my
POME is available especially in pilot scale operation. Composting is basically a biodegradation process in which organic wastes are transformed and stabilized by the metabolic activities of a succession of mixed microbial population. The enzymatic process and pre-dominant microbes are specific to the materials to be composted and need to be determined by specific experiments. Thus, the information would provide specific design and operational parameters for effective composting of EFB and POME.

The decomposition of cellulose is mediated by group of enzymes collectively called as cellulases. The decomposition of organic waste during the composting process is carried out by a succession of microbial communities, which is critical for the utilization of complex substrates such as cellulose, hemicellulose and lignin [4]. DGGE is a useful tool to reveal microbial succession during composting. Many researchers showed the efficiency of this molecular method to detect the shift of microbial changes in composting process [5-7]. Therefore, the aim of this study was mainly focused on the observation and identification of enteric microorganisms, biochemical changes and cellulase profiles during the cocomposting of EFB with partially treated POME in pilot scale. DGGE technique was used to characterize microbial communities and diversity during the composting process. 


\section{MATERIALS AND METHODS}

\section{Pilot-Scale Composting Plant}

This research was conducted at pilot-scale composting plant in FELDA Maokil, Johor, Malaysia. A total of 202 windrows were incubated at the composting site which consists of two field area (13 hectare). The composting materials were obtained from the oil palm processing mill. The shredded EFB and partially treated POME were mixed at 40 tonnes and 120 tonnes, respectively.

\section{Composting Establishment}

The tipper lorry was used to lay down the shredded EFB on the composting ground to form a long conical shaped of windrow (40m L x $3 \mathrm{~m} \mathrm{~W} \times 1.5 \mathrm{~m} \mathrm{H})$. Partially treated POME (anaerobic pond) was added to each of the piles every three days interval to adjust the final moisture content of $65-70 \%$. The addition of POME was stopped one to two weeks prior to harvesting to avoid the final product from being too wet. The windrow was covered throughout the composting period except during spraying of POME and turning process. The piles were turned over one to three times per week to maintain an even distribution of moisture and prevent the buildup of heat.

\section{Sampling}

A $2 \mathrm{~kg}$ sample was collected at different locations of the windrow: bottom, core and surface. The samples were divided into two parts. One part was stored at $4^{\circ} \mathrm{C}$ while the other part was air dried, and then passed through $2 \mathrm{~mm}$ sieve. All experiments were done in triplicates.

\section{Physicochemical and Bacterial Count Analysis}

The temperature at the top, middle and bottom layers of the interior of the heaps was monitored by using compost monitoring device for temperature and oxygen. $\mathrm{pH}$ meter and moisture analyzer were used in this study for $\mathrm{pH}$ and moisture content analysis. Total carbon and total nitrogen were measured using a CNHS analyzer. Plate count method was used to obtain viable bacterial count. Observation of the compost structure was carried out using scanning electron microscopy (SEM).

\section{Extraction Procedures for Cellulases Analysis}

The mixed compost sample $(5 \mathrm{~g})$ was extracted with 50 $\mathrm{mL}$ of $0.01 \mathrm{M}$ phosphate buffer $(\mathrm{pH} 7)$ at $4^{\circ} \mathrm{C}$. Then, the sample was centrifuged at $5000 \mathrm{rpm}, 4^{0} \mathrm{C}$ for 20 minutes and the supernatant was stored at $-20^{\circ} \mathrm{C}$. The supernatant obtained was then used for the analysis of cellulases activities [8].

\section{Enzyme Assays and Reducing Sugar Concentration}

Enzyme assays for CMCase were performed by measuring reducing sugars from $2 \%$ carboxymethylcellulose (CMC). Filter paperase (FPase) activity was determined by estimating the reducing sugars from Whatman filter paper no 1. The B-glucosidase activity was determined using $\mathrm{p}$ nitrophenol- $\beta$-D-glucopyranoside as substrate. The reducing sugars released were analyzed according to the dinitrosalicylate (DNS) method. One unit (U) of enzyme activity was defined as the amount of enzyme required to liberate $1 \mu \mathrm{mol}$ of product per min. Cellulases enzyme assays (CMC, FPase, B-glucosidase) and reducing sugars determination was followed the methods reported by Shahrim et al., 2008 [8]. Enzyme yield was expressed as U/g of dry substrate [8].

\section{Nucleic Acid Extraction}

Total genomic DNAs were extracted from approximately $1.0 \mathrm{~g}$ of mixed compost samples using Ultra Clean Soil DNA Isolation Kit (MoBio laboratories, USA). The DNA extracted was checked for size and quality. Extracted DNA samples were then purified using DNA purification kit with GeneCleanR Turbo kit (MP Biomedicals, USA).

\section{Polymerase Chain Reaction}

The variable region (V3 region) of the 16S rDNA was amplified by using PCR primers. The PCR amplifications were performed in $50 \mu \mathrm{l}$ volumes containing approximately $1 \mu 1$ template DNA, $25 \mu 1$ Ex Taq DNA polymerase (Takara Shuzo, Japan), $20 \mu 1$ ultra pure water (Millipore) and $2 \mu 1$ of each primer: $341 \mathrm{~F}$-with a 40-bp GC clamp (5'-CGC CCG $C C G C G C$ GCG GCG GGC GGG GCG GGG GCA CGG $G G G$ GCC TAC GGG AGG CAG CAG -3') and 518R (5'ATT ACC GCG GCT GCT GG-3'). Combination of these primers generates a PCR fragment of about $200 \mathrm{bp}$. The PCR cycling was performed using a Takara PCR Thermal Cycler. The temperature used was as follows; $94^{\circ} \mathrm{C}$ for 3 min followed by 30 cycles of $52^{\circ} \mathrm{C}$ for $1 \mathrm{~min}, 72^{\circ} \mathrm{C}$ for $1 \mathrm{~min}, 94^{\circ} \mathrm{C}$ for $1 \mathrm{~min}$ and then continue at $52^{\circ} \mathrm{C}$ for $1 \mathrm{~min}$ with final extension steps at $72^{\circ} \mathrm{C}$ for $10 \mathrm{~min}$.

\section{Denaturing Gradient Gel Electrophoresis}

DGGE was performed with a D-Gene system (BioRad laboratories, USA). PCR products were separated on a $1.5 \mathrm{~mm}$ thick vertical gel containing $8 \%(\mathrm{w} / \mathrm{v})$ acrylamide and a linear gradient of the denaturants urea and formamide, increasing from $30 \%$ at the top of the gel to $70 \%$ at the bottom. One hundred percent of denaturant corresponds to $7 \mathrm{M}$ urea and $40 \%(\mathrm{v} / \mathrm{v})$ formamide. The PCR products (200ng DNA) were then applied to the individual lanes in the gel. Electrophoresis was performed in a TAE buffer and a constant voltage of $200 \mathrm{~V}$ was applied to the submerged gel for $5 \mathrm{~h}$ at $60^{\circ} \mathrm{C}$. After electrophoresis, the gels were stained with $\mathrm{SYBR}^{\mathrm{R}}$ Green nucleic Acid Gel Stain for 30min and then rinsed with water and photographed on a UV transillumination table. The computerized images were then inverted to negative images. Small pieces of selected DGGE bands viewed on the UV were excised from the gel with pasteur

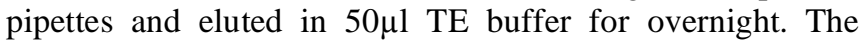
DNA fragments in the gels were washed and directly reamplified with the same primer. The PCR products were confirmed by DGGE as a single band and then sequenced. Before sequencing, the PCR products were purified by Qiaquick PCR Purification kit (QIAGEN, Hilden, Germany).

\section{Sequencing and Band Characterization}

The PCR products were sent for sequencing. Sequence similarity searches were conducted using the BLAST (Basic Local Alignment Search Tool) network service of the GenBank database through website (http://www.ncbi.nlm.nih. gov/) and Ribosomal Database Project II (RDP) to identify the nearest relatives of the partially sequenced $16 \mathrm{~S}$ rRNA genes and the excised dominant bands. 
Table 1. Characteristics of Raw Materials and Compost Samples for the Denaturant Gradient Gel Electrophoresis (DGGE) Analysis

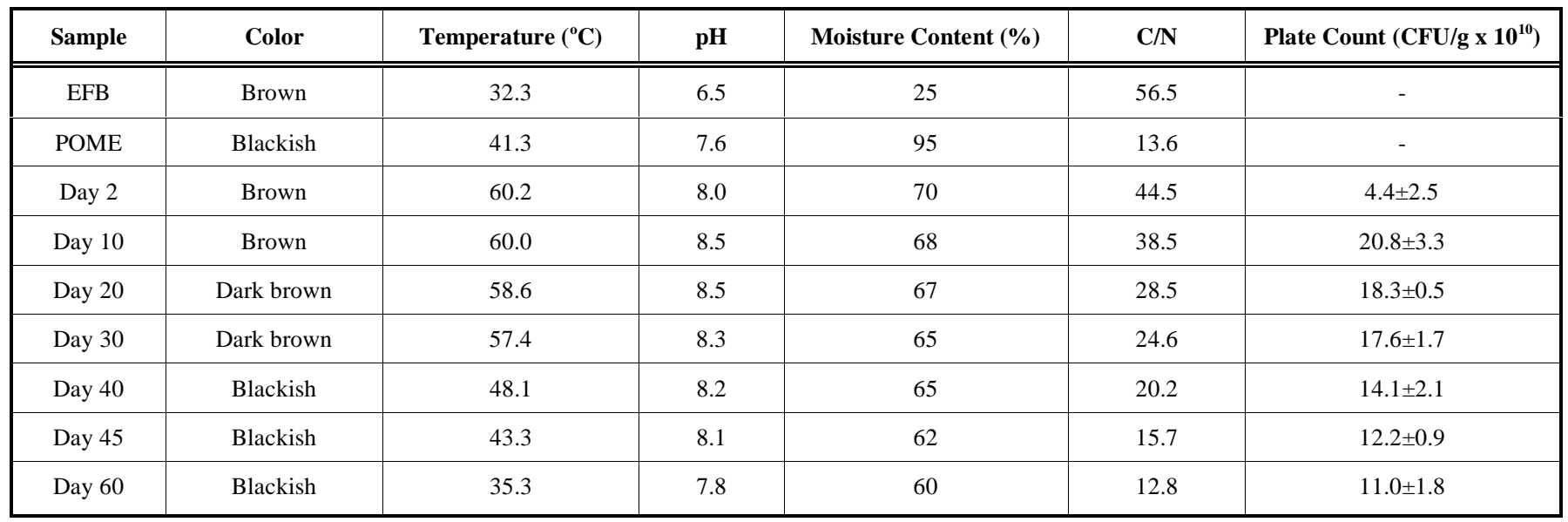

\section{RESULTS AND DISCUSSION}

\section{Physicochemical Characteristics}

The changes in temperature, moisture content, $\mathrm{pH}, \mathrm{C} / \mathrm{N}$ and colour throughout composting process were monitored as shown in Table 1. The final matured compost was found blackish in color and has an earthy smell. Based on temperature profile, two compost phases were involved; thermophilic and curing phase (Table 1). The temperature in the compost piles reached about $60^{\circ} \mathrm{C}$ after second day of composting and fluctuated in the range of $50-60^{\circ} \mathrm{C}$ until day 40 and gradually descended to ambient values thereafter. This result might be due to the large amount of readily digestible components contained in the POME added which were immediately available for microbes. It was observed that the moisture content throughout the treatment was 65$70 \%$ and gradually decreased to $60 \%$ for final compost. The higher moisture content $(65 \%)$ enhanced the microbial activities in the composting process, resulting in higher biodegradation of organic compounds [9].

The $\mathrm{pH}$ profile increased gradually from 7.8 to about 8.0 on the second day treatment and remained at 8.2-8.5 as the temperature increased in the thermophilic phase indicating weak alkaline condition of the system (Table 1). The $\mathrm{pH}$ was then gradually decreased afterwards and reached about 7.8 in the final compost. The initial $\mathrm{C} / \mathrm{N}$ ratio of the piles was about 44.5 and decreased to 12.8 (Table 1) after 60 days of treatment. In the latter stage of treatment, the number of bacteria decreased when most of the easily metabolisable carbon constituents have already been exhausted.

\section{SEM Analysis and Change in Cellulolytic Activities}

The structure of EFB before and during composting treatment was viewed under SEM as shown in Figs. (1 to 3). SEM observation showed that the surface structure of the untreated shredded EFB consisted of firmly bound threads of lignin with smooth surface along the structure (Fig. 1a) while the outer surface of treated EFB seems has been altered with the presence of many holes indicating the lignin has been disrupted (Fig. 3).

Moreover, there were many silica bodies found on the strand surface of the EFB structure at initial composting process (Fig. 2). This result was in agreement with previous data published by Law et al., 2007 [10], who reported that the silica bodies were spread uniformly over the EFB strand's surface. Interestingly, most of the silica bodies on the EFB strand were removed when the composting process achieved at day 20 of treatment (Fig. 3). After day 40 of treatment, the inner structure of EFB compost was strongly disrupted. This phenomenon might be due to the combination of thermophilic temperature $\left(>50^{\circ} \mathrm{C}\right)$ which occurred from day 3 to day 40 of treatment, microbial degradation and the frequent turning on the composting piles. The removal of silica bodies would enhance the microbial penetration in the composting process.

The changes of CMCase, FPase and beta-glucosidase were measured (Fig. 4). After day 3 of treatment, when the temperature increased into thermophilic phase $\left(>50^{\circ} \mathrm{C}\right)$, the cellulase activity also increased rapidly. During the thermophilic phase, high temperatures accelerated the breakdown of proteins, fats and complex carbohydrates such as cellulose and hemicellulose [11]. The highest activity of CMCase, FPase and $\beta$-glucosidase was detected at day 30 of treatment with values of $13.6,4.1$ and $20.3 \mathrm{U} / \mathrm{g}$ of dry substrate, respectively. During the curing phase, $\mathrm{C} / \mathrm{N}$ was less than 15 (day 45) while the cellulase activity remained unchanged until the end of the process.

CMCase activity started to increase until day 10 and showed the maximum activity at day 30 before it slightly declined afterwards. The shredded EFB used in this study may result in an enlargement of inner surface area of substrate particles, and was accomplished by partial solubilization or degradation of hemicellulose and lignin. The activity of FPase corresponded to the degradation of cellulosic material from EFB after the action of CMCase at the early stage. Since CMCase is not very active against crystalline cellulose, FPase will take over the action to degrade the insoluble cellulose. There is a synergistic effect between CMCase and FPase. These two enzymes must be incorporated towards each other so that complete hydrolysis of cellulose was achieved. The highest amount of secreted $\beta$-glucosidase was at day $30(20.3 \mathrm{U} / \mathrm{g})$ and slightly decreased afterwards. The activity of $\beta$-glucosidase was correlated to the amount of cellobiose produced from the action of FPase. Based on the 
a) Shredded EFB

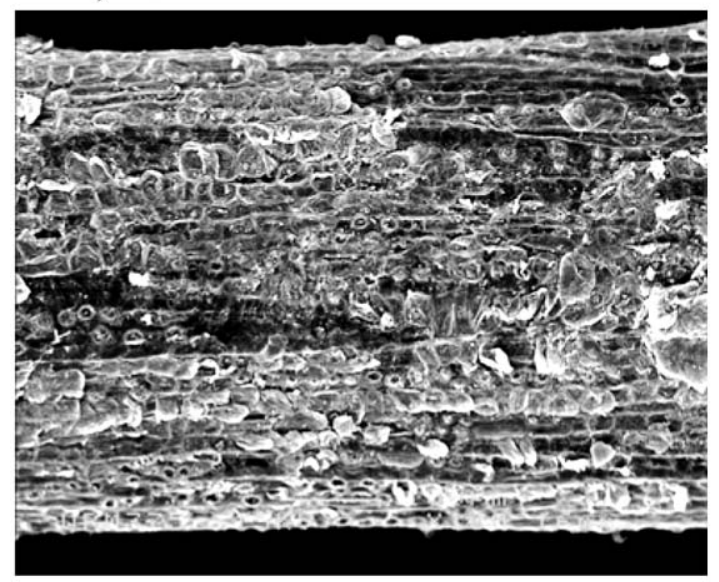

(180X magnification)

b) Partially treated POME

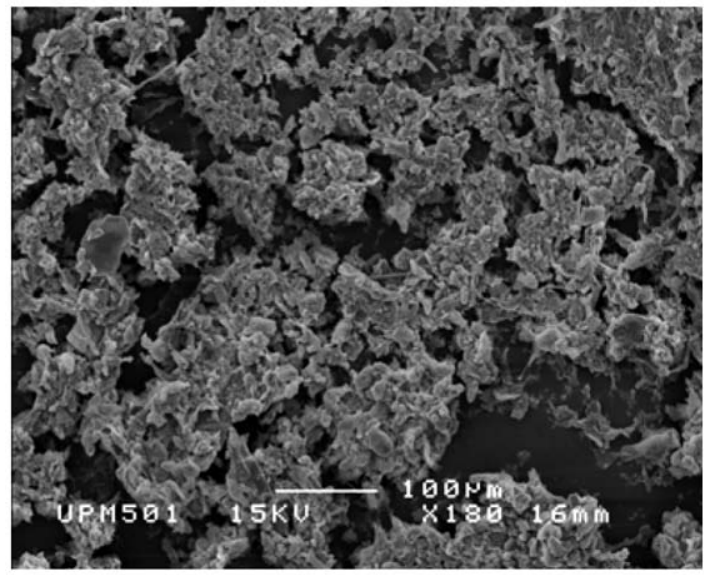

(180X magnification)

Fig. (1). SEM of shredded EFB and partially treated POME.
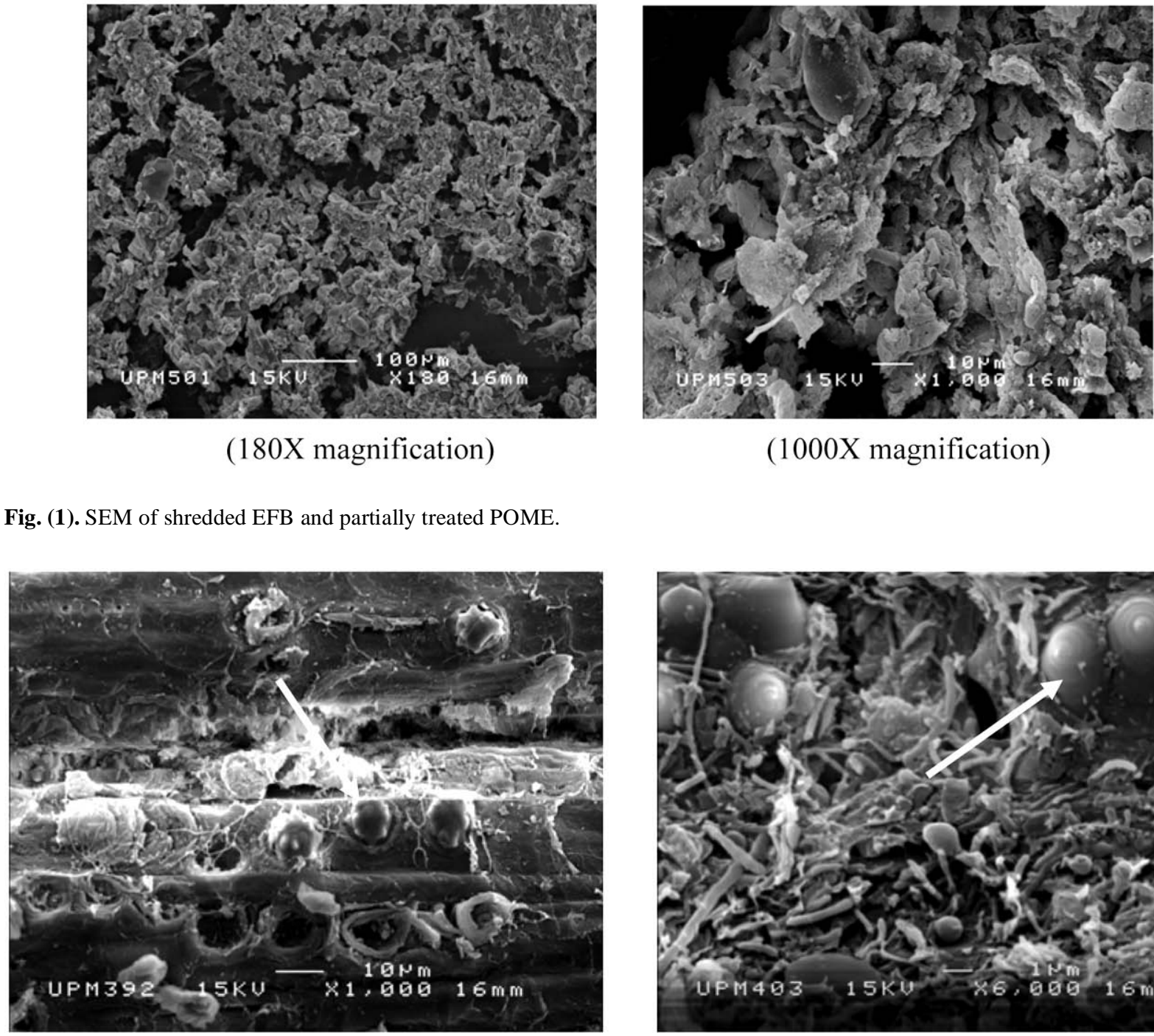

(1000X magnification)

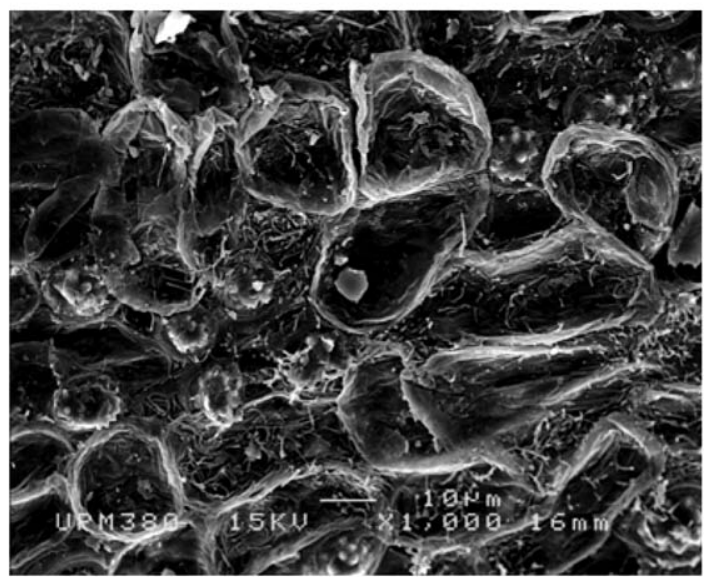

(1000X magnification)

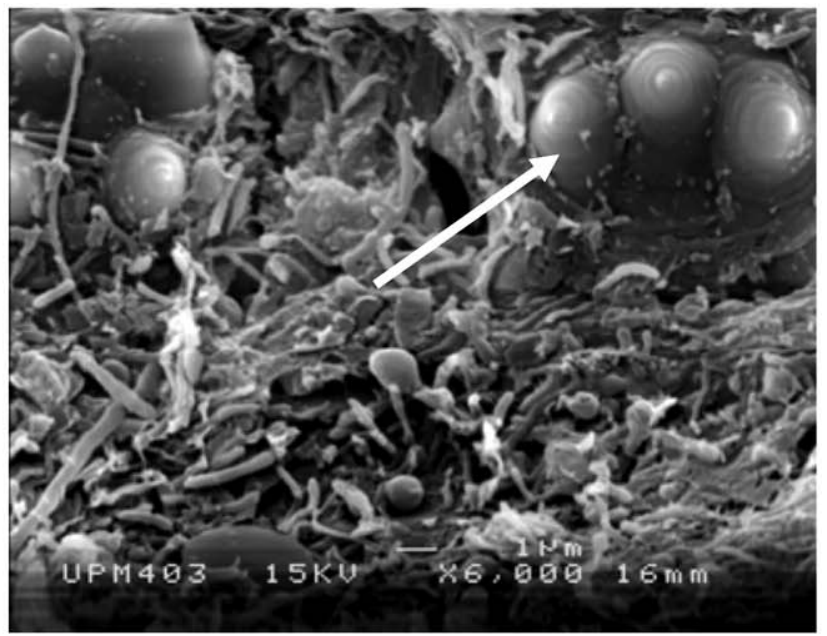

Fig. (2). SEM of EFB compost at day 2 (arrow shows the silica body found on the EFB strand at 1000 and $6000 \mathrm{X}$ magnification). 


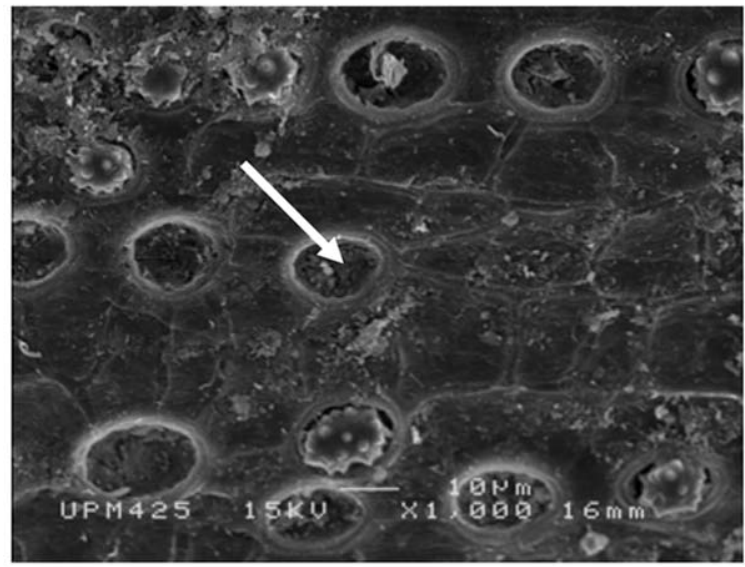

Day 10

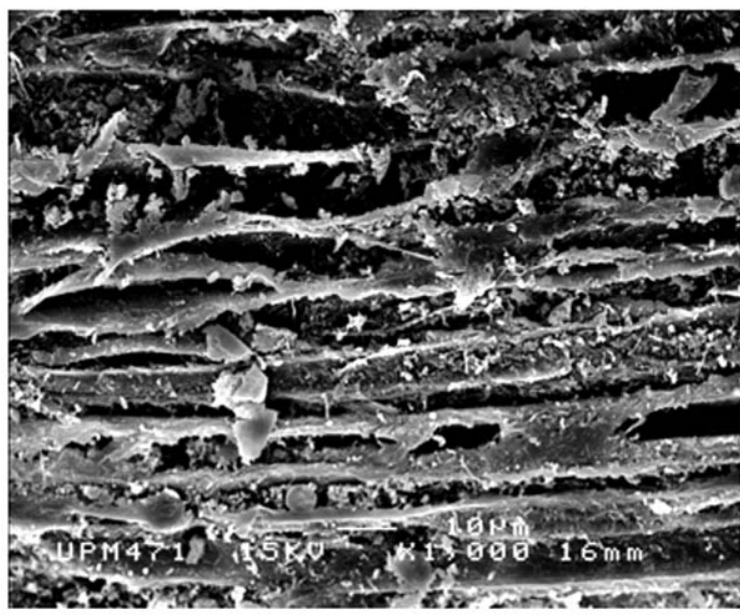

Day 40

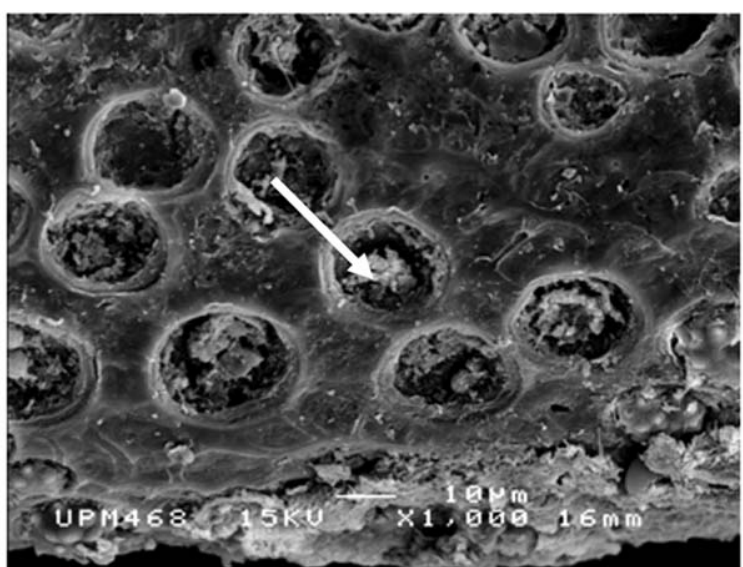

Day 20

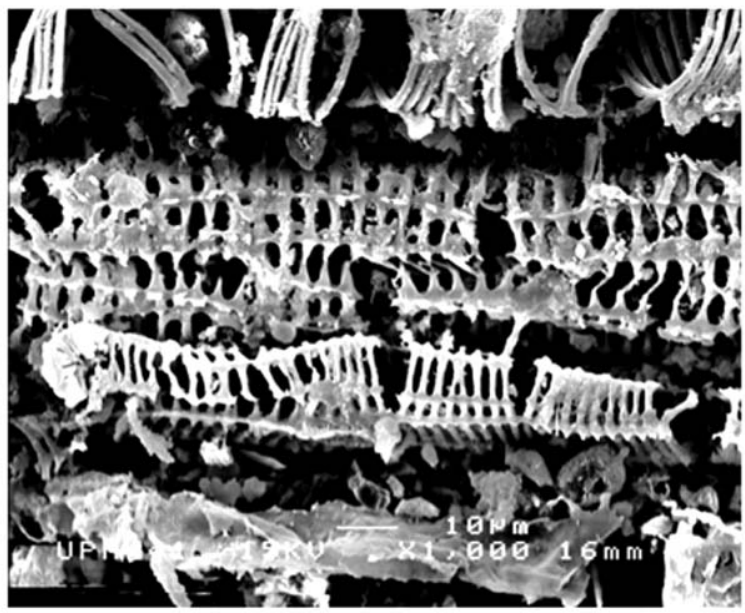

Day 60

Fig. (3). SEM of EFB compost at day 10, day 20, day 40 and day 60 at $1000 \mathrm{X}$ magnification (arrow shows the silica body found on the EFB strand).

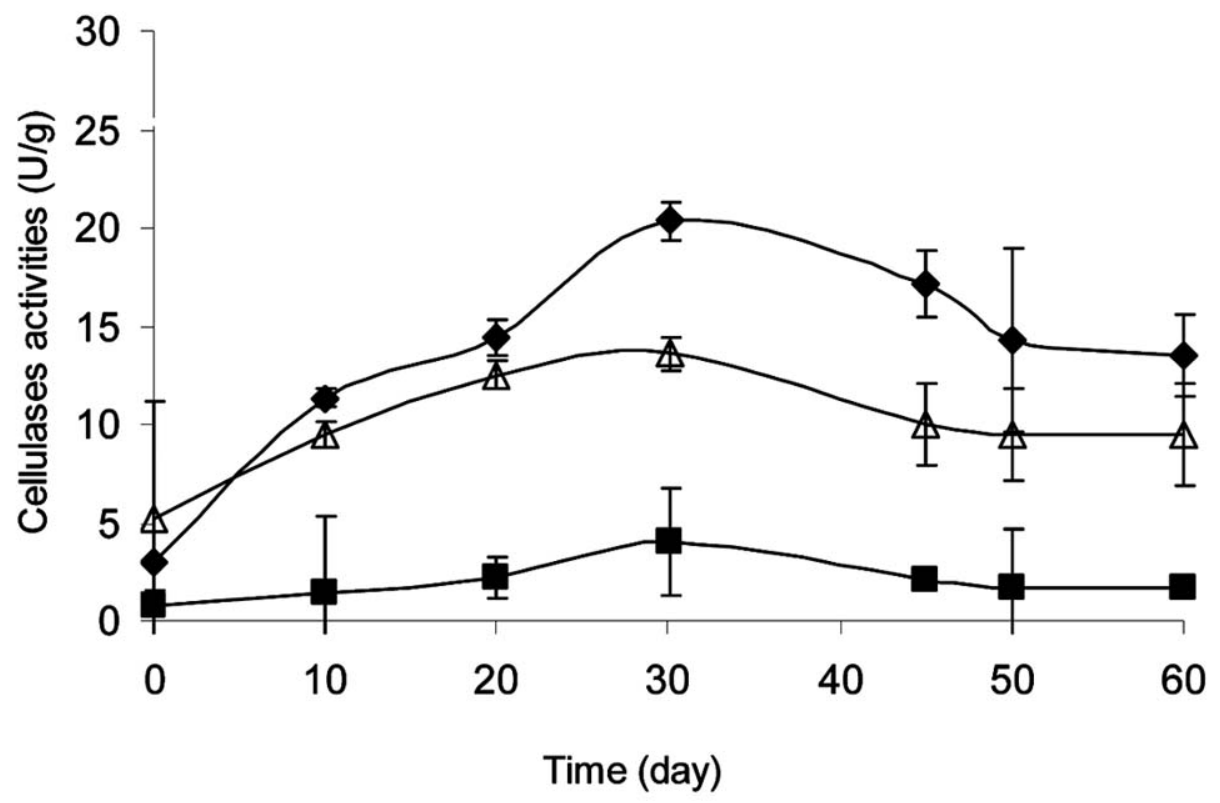

Fig. (4). Change in cellulase activities (U/g dry substrate) during the co-composting of EFB and treated POME. Values are means of three replicates \pm standard errors. ( $\mathbf{m}$ FPase; $\Delta$ : CMCase; $\$$-glucosidase). 


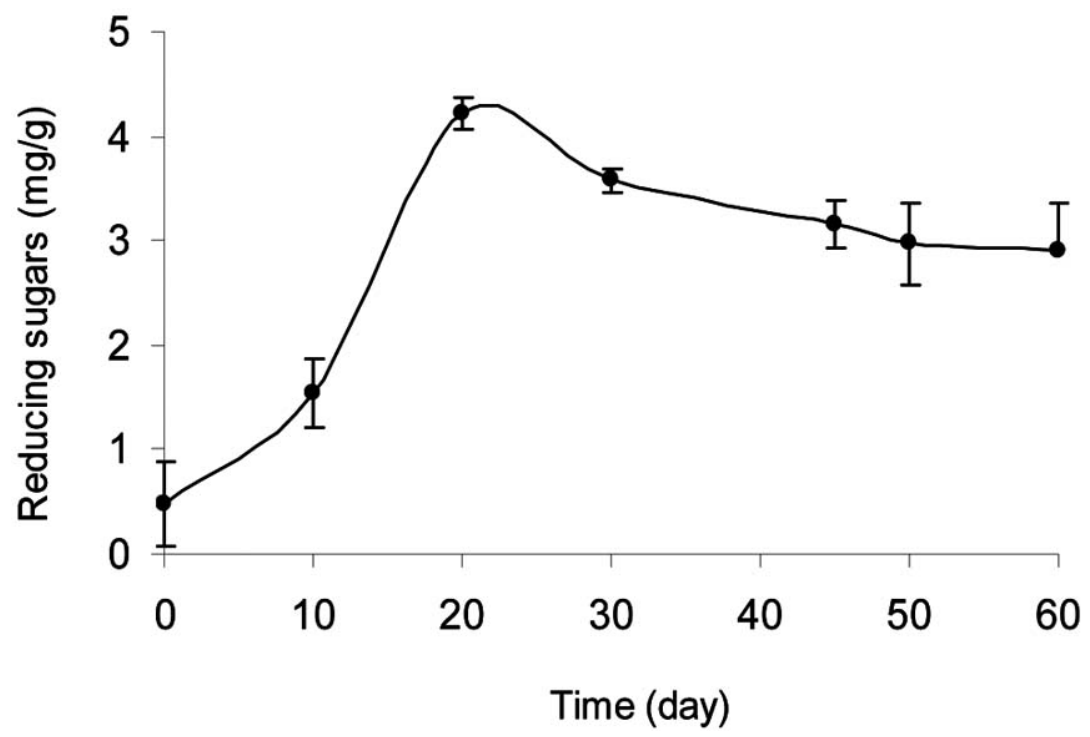

Fig. (5). Profiles of reducing sugar production (mg/g dry substrate) throughout composting.

high activity of cellulases produced during composting indicated the degradation of EFB and were in agreement with the SEM results. The profile of reducing sugar production is shown in Fig. (5). The highest reducing sugar produced was detected at day $20(4.2 \mathrm{mg} / \mathrm{g}$ of dry substrate $)$. The decreased of reducing sugars at day 30 might be due to the sugar consumption by the microorganism. The reducing sugars continued to decrease and remained stable during curing phase (C/N: 15.8) after 45 days of treatment.

\section{DGGE Analysis in Composting Process}

In this study, composting process in pilot scale was analyzed in terms of biochemical aspects and bacterial populations evaluated by PCR-DGGE analysis. The results showed that the position and intensities of most bands did not change significantly as the age of composting proceeded (Fig. 6). These findings suggest that bacterial communities did not change greatly throughout the composting treatment. However, the detailed analyses of each sample showed the pres-

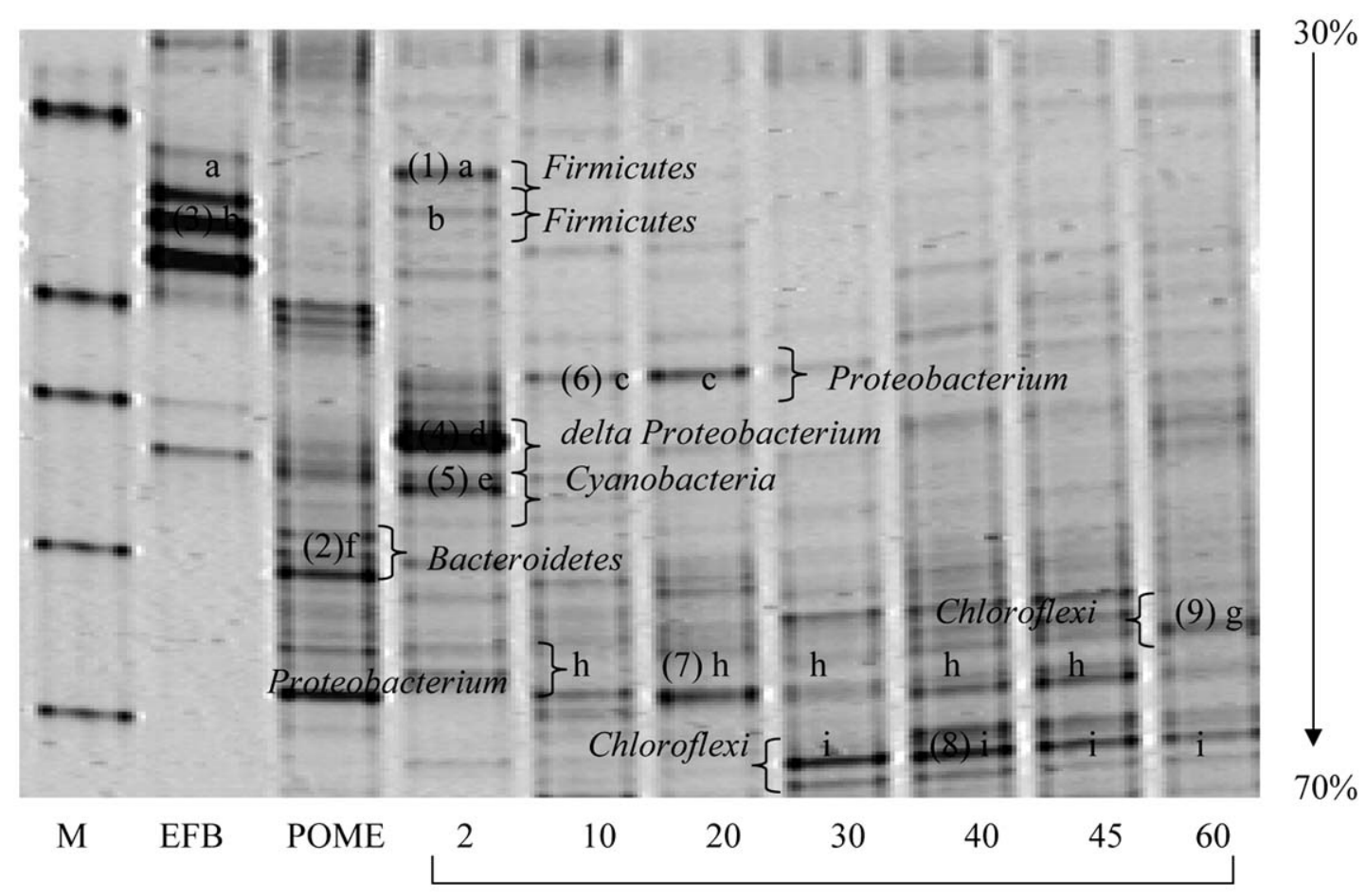

Day of composting

Fig. (6). Comparison of the DGGE banding patterns of microbial communities of the substrates at various composting time. The arrow on the right indicates the gradient of DNA denaturants. 
Table 2. Phylogenetic Affiliation of Excised DGGE Bands

\begin{tabular}{|c|c|c|c|c|c|c|c|}
\hline Band & $\begin{array}{l}\text { Nearest Relative } \\
\text { (Accession) }\end{array}$ & $\begin{array}{l}\text { Similarity } \\
\quad(\%)\end{array}$ & Source & Phylogeny & $\begin{array}{c}\text { Nearest Known Relatives } \\
\text { (Accession) }\end{array}$ & $\begin{array}{l}\text { Similarity } \\
\quad(\%)\end{array}$ & Source \\
\hline 1 & $\begin{array}{l}\text { Uncultured bacterium } \\
\text { clone:C21-397 } \\
(\mathrm{AB} 366968.1)\end{array}$ & 94 & EFB & $\begin{array}{l}\text { Firmicutes } \\
\text { "Bacili" }\end{array}$ & $\begin{array}{l}\text { Lactobacillus agilis, strain: } \\
\text { PIL54 (AB300541.1) }\end{array}$ & 94 & $\begin{array}{l}\text { Solid waste } \\
\text { compost }\end{array}$ \\
\hline 2 & $\begin{array}{c}\text { Uncultured biogas } \\
\text { bacterium clone } \\
\text { ATB-KS-1413 } \\
\text { (EF686945.1) }\end{array}$ & 96 & POME & Bacteroidetes & $\begin{array}{c}\text { Uncultured Bacteroidetes } \\
\text { bacterium clone } 1217 \\
\text { (EF109915) }\end{array}$ & 91 & $\begin{array}{l}\text { High-temperature } \\
\text { volcanic }\end{array}$ \\
\hline 3 & $\begin{array}{l}\text { Uncultured bacterium } \\
\text { clone:C21-397 } \\
\text { (AB366968.1) }\end{array}$ & 94 & compost & $\begin{array}{l}\text { Firmicutes } \\
\text { "Bacili" }\end{array}$ & $\begin{array}{c}\text { Lactobacillus sp. } \\
\text { Autruche } 4 \\
\text { (DQ418552.1) }\end{array}$ & 92 & $\begin{array}{l}\text { Probiotics on } \\
\text { chicks }\end{array}$ \\
\hline 4 & $\begin{array}{l}\text { Uncultured bacterium } \\
\text { clone } 31 \mathrm{~b} 02 \\
(\text { EF515618.1) }\end{array}$ & 90 & compost & $\begin{array}{c}\text { Proteobacterium } \\
\text { "ס-proteobacterium" }\end{array}$ & $\begin{array}{l}\text { Uncultured Desulfobac- } \\
\text { teraceae bacterium clone } \\
\text { cLaKi-StA5 (AJ582696.1) }\end{array}$ & 90 & $\begin{array}{c}\text { Full-scale } \\
\text { anaerobic } \\
\text { bioreactor sludge }\end{array}$ \\
\hline 5 & $\begin{array}{l}\text { Uncultured bacterium } \\
\text { C051 (AF128638.1) }\end{array}$ & 94 & compost & Cyanobacteria & $\begin{array}{l}\text { Uncultured } \text { Oscillatoriales } \\
\text { cyanobacterium } \\
\text { (AY795633.2) }\end{array}$ & 94 & Soil \\
\hline 6 & $\begin{array}{l}\text { Uncultured bacterium } \\
\text { clone biogas-DT-B19 } \\
\text { (DQ419742.1) }\end{array}$ & 86 & compost & Bacteria & $\begin{array}{l}\text { Uncultured proteobacte- } \\
\text { rium clone GASP- } \\
\text { KA1W1_C01 } \\
\text { (EU297196.1) }\end{array}$ & 86 & Crop land \\
\hline 7 & $\begin{array}{c}\text { Uncultured compost } \\
\text { bacterium,clone G818 } \\
\text { (AJ011365.1) }\end{array}$ & 91 & compost & Bacteria & $\begin{array}{l}\text { Uncultured Proteobacte- } \\
\text { rium isolate DGGE band } \\
\text { CSMC-M } \\
\text { (EU025084.1) }\end{array}$ & 91 & Hot Compost \\
\hline 8 & $\begin{array}{l}\text { Uncultured bacterium } \\
\text { clone DGGE band C-2 } \\
\text { (DQ082874.1) }\end{array}$ & 96 & compost & Bacteria & $\begin{array}{l}\text { Uncultured Chloroflexi } \\
\text { bacterium clone GASP- } \\
\text { KB1S2_D03 } \\
\text { (EU297607.1) }\end{array}$ & 96 & Soil \\
\hline 9 & $\begin{array}{l}\text { Uncultured Chloroflexi } \\
\text { bacterium clone MSB- } \\
\text { 5B12 (DQ811882.1) }\end{array}$ & 93 & compost & Chloroflexi & $\begin{array}{l}\text { Uncultured Chloroflexi } \\
\text { bacterium clone } \\
\text { MSB-5A11 (DQ811881.1) }\end{array}$ & 93 & Soil \\
\hline
\end{tabular}

ence of distinguishable patterns that revealed the different bacterial genera or species in each community (Table 2). Moreover, the bacteria involved in the composting process might not totally derived from the starting materials, because the DGGE profiles of compost samples were different as compared to the band detected in the raw material (Fig. 6). It was shown that different microbial populations from those in the raw material rapidly developed in the composting process. The result was supported by klamer and Baath, 1998 [12] who reported that the microbes proliferating in the composting processes would be adapted to the composting environment and selected by factors within the composting materials.

The results obtained in this study indicated that the prominent members were mainly uncultured and unidentified bacteria. This result is in agreement with previous studies [13] on the identification of thermophilic bacteria in EFB compost. The recovered sequences from major bands were distributed unevenly among 6 phylogenetic groupings: Firmicutes (2 sequences), Bacteroidetes (1 sequence), Cyanobacteria (1 sequence), delta-Proteobacterium (1 sequence), Proteobacterium (2 sequence), and Chloroflexi (2 sequences) (Fig. 6). The majority of these bacteria had high similarity to sequences of known bacteria or environmental sequences ( 8 sequences, equal to or greater than $90 \%$ identity), although one sequence, uncultured bacterium clone biogas-DT-B19 (proteobacterium) for sample of day 10 and 20 , was more distantly related to known sequences $(<90 \%$ identity) (Table 2).

In this study, the phylum of Firmicutes, the closest to Lactobacillus, was the only prominent detected in EFB (Table 2). This result could be attributed to the remaining oil content in the EFB. It can be seen that the $\mathrm{pH}$ of the shredded EFB was slight in acidic condition (6.5). According to 
Hemmi et al., 2004 [14], in the presence of oil, lactic acid bacteria become the major strain of microflora. The freshly sterilized empty fruit bunches usually still contained about $2 \%$ of crude palm oil [15]. The uncultured bacterium clone C21-397 (AB366968.1) detected in this study has been found during start-up period of large scale solid waste compost as reported by Watanabe et al., 2007 [16], while in POME (anaerobic pond) it was dominated by the members of the phylum bacteroidetes (uncultured biogas bacterium) (Table 2).

At the beginning of composting, when the POME was added onto EFB and turned, sample of day two was taken and analyzed through DGGE analysis. Three major bands were excised and known as a group of cyanobacteria, deltaproteobacterium and firmicutes (Fig. 6). The phylum of firmicutes existed at this time may be due to the prominent bacterial detected in EFB (oil). Once the temperature of the pile increased to $44^{\circ} \mathrm{C}$ (thermo-tolerant), the temperature encouraged other predominant bacterial presence, namely cyanobacteria and delta-proteobacterium group. The closest known relative to the excised band number $4 \mathrm{~d}$ (deltaproteobacterium) was uncultured desulfobacteraceae. The uncultured bacterium detected for the excised band number 5e (cyanobacteria) was closest to oscillatoriales cyanobacterium.

Major band number $6 \mathrm{c}$ which was detected at day 10 and 20 was identified as uncultured bacterium clone biogas and closest to the phyla proteobacterium bacteria. During this time, the composting was still unstable and this bacterium could be obtained from the POME added to the piles, while the major bands of $7 \mathrm{~h}$, which were consistently present from day 10 to day 45 , were affiliated to uncultured compost bacterium. The closest known relative of this bacterium was proteobacterium and was previously isolated from hot compost sample [17]. However, once the composting condition achieved $\mathrm{C} / \mathrm{N}$ about 25 (pre-matured compost) at day 35, the uncultured bacterium closest to chloroflexi bacterium was dominated in the compost together with proteobacterium (Fig. 6). After day 45 (C/N ratio: 15), only uncultured chloroflexi bacterium was detected. The phyla chloroflexi are known to contain bacteria that are highly abundant in the environment, even though most of them are difficult to cultivate [18]. Chloroflexi and proteobacteria were also detected as prominent microbial community in soil [19].

The sequences of the amplified DNA bands in this DGGE study also confirmed the stability of the microflora. For example band $7 \mathrm{~h}$ (uncultured compost bacterium) remained as the major microorganisms for over 6 weeks. The results also revealed that all of the pre-dominant sequences were most closely related to several species of uncultured bacteria found in different compost samples (Table 2). The results obtained in this study suggested that these bacteria play important roles in the co-composting of EFB and partially treated POME in pilot scale.

\section{CONCLUSIONS}

The adjustment of composting conditions such as pile size, aeration, moisture content, $\mathrm{pH}$ and temperature is crucial. This would increase microbial populations and their hydrolytic enzyme activities. The organic matter decomposition was increased as shown by the reduction of $\mathrm{C} / \mathrm{N}$ ratio.
The results of DGGE analysis indicated that the prominent microbes during the composting of EFB and partially treated POME were mainly uncultured and unidentified bacteria.

\section{ACKNOWLEDGEMENTS}

The project was sponsored by Kyushu Institute of Technology, Japan and Felda Palm Industries Sdn. Bhd., Malaysia. The authors would like to thank the management of Maokil Palm Oil Mill for their cooperation throughout the study. This study was financially supported by FELDA grant (67001) and Japan Society for Promotion of Science (JSPS).

\section{REFERENCES}

[1] Baharuddin AS, Wakisaka M, Shirai Y, Abd-Aziz S, Abdul Rahman NA, Hassan MA. Co-composting of empty fruit bunches and partially treated palm oil mill effluents in pilot scale. Int $\mathbf{J}$ Agric Res 2009; 4(2): 69-78

[2] Gea T, Artola A, Sort X, Sanchez A. 2005. Composting of residuals produced in the Catalan wine industry. Compost Sci Util 2005; 13: 168-174.

[3] Virginia SA, Francisco JF, Jose V, Lourdes R. Enhancing the cocomposting of olive mill wastes and sewage sludge by the addition of an industrial waste. Bioresour Technol 2008; 99: 6346-53.

[4] Hiroaki T, Kodaira S, Kimoto A, Nashimoto M, Takagi M. Microbial communities in the garbage composting with rice hull as an amendment revealed by culture-dependent and - independent approaches. J Biosci Bioeng 2006; 101 (1): 42-50.

[5] Haruta S, Kondo M, Nakamura K, et al. Microbial community changes during organic solid waste treatment analyzed by double denaturing gradient gel electrophoresis and fluorescence in situ hybridization. Appl Microbiol Biotechnol 2002; 60: 224-231.

[6] Ishii K, Fukui M, Takii S. Microbial succession during a composting process as evaluated by denaturing gradient gel electrophoresis analysis. J Appl Microbiol 2000; 89: 768-777.

[7] Tanahashi T, Murase J, Matsuya K, Hayashi M, Kimura M, Asakawa S. Bacterial communities responsible for the decomposition of rice straw compost in a Japanese rice paddy field estimated by DGGE analysis of amplified 16S rDNA and $16 \mathrm{~S}$ rRNA fragments. Soil Sci Plant Nutr 2005; 51: 351-360.

[8] Shahrim Z, Sabaratnam V, Rahman NAA, Abd-Aziz S, Hassan MA, Karim MIA. Res J Microbiol 2008; 1-11.

[9] Xiujin L, Zhang R, Pang Y. Characteristics of dairy manure composting with rice straw. Biores Technol 2008; 99: 359-367.

[10] Law NL, Daud WRW, Ghazali A. Morphological and chemical nature of fiber strands of oil palm empty fruit bunch (OPEFB). Bioresource 2007; 2(3): 351-360.

[11] Olfa F, Jedidi N, Hassen A. Behaviour of main microbiological parameters and of enteric microorganisms during the composting of municipal solid wastes and sewage sludge in a semi-industrial composting plant. Am J Environ Sci 2008; 4 (8): 103-110.

[12] Klamer M, Baath E. Microbial community dynamics during composting of straw material studied using phospholipid fatty acid analysis. FEMS Microbiol Ecol 1998; 27: 9-20.

[13] Goh CM, Liew PWY, Jong BC, Thong KL. Bacterial diversity of decomposing oil palm empty fruit bunches based on PCR and denaturing gradient gel electrophoresis of $16 \mathrm{~S}$ rRNA gene fragments. $29^{\text {th }}$ Symposium of the Malaysian Society of Microbiology. Terengganu: $24^{\text {th }}-26^{\text {th }}$ November 2007.

[14] Hemmi H, Shimoyama T, Nakayama T, Hoshi K, Nishino T. Molecular biological analysis of microflora in a garbage treatment process under thermoacidophilic conditions. J Biosci Bioeng 2004; 97(2): 119-126.

[15] Mohamad H, Ridzuan R. Anis M, et al. Research on development of oil palm biomass utilisation in wood-based industries. Malaysian Palm Oil Board 2002; 2: p. 1-5.

[16] Watanabe K, Nagao N, Toda T, Kurosawa N. Bacterial community succession during a start-up period of large-scale composting reac- 
tor as evaluated by DGGE and clone analysis 2007. Available from:http://www.ncbi.nlm.nih.gov/ [Cited 2008 Oct 10].

[17] Blanc MP. Marilley L, Beffa T, Aragno M. Thermophilic bacterial communities in hot composts as revealed by most probable number counts and molecular (16S rDNA) methods. FEMS Microbiol Ecol 1999; 28: 141-9.
[18] Fracchia L, Dohrmann AB. Martinotti MG, Tebbe CC. Bacterial diversity in a finished compost and vermicompost: Differences revealed by cultivation-independent analyses of PCR-amplified 16S rRNA genes. Appl Microbiol Biotechnol 2006; 5: 1-11.

[19] Toyota K, Kuninaga S. Comparison of soil microbiology community between soils amended with or without farmyard manure. Appl Soil Econ 2006; 33: 39-48.

Received: January 30, 2009

(c) Baharuddin et al.; Licensee Bentham Open.

This is an open access article licensed under the terms of the Creative Commons Attribution Non-Commercial License (http://creativecommons.org/licenses/by-nc/3.0/) which permits unrestricted, non-commercial use, distribution and reproduction in any medium, provided the work is properly cited. 